\title{
IDENTIFIKASI KADAR VITAMIN C PADA DAGING DAN KULIT BUAH NAGA MERAH (Hylocereus Polyrhizus) DENGAN METODE SPEKTROFOTOMETRI UV-VISIBLE
}

\author{
Aminah. S, Kardila, Rezky Zantrie, Romauli Anna Teresia Marbun \\ Institut Kesehatan Medistra Lubuk Pakam, Jalan Sudirman No.38 Lubuk Pakam \\ e-mail : syarifuddinami6@gmail.com \\ DOI : https://doi.org/10.35451/jfm.v2i1.285
}

\section{ABSTRACT}

Introduction: Vitamin $C$ is one of the nutrition acted as a antioxidants and effective addres free radicals can be destructive cells or tissue. Fruits are a source of, which is a dragon red. Part of the dragon red during this rarely used is the skin. The dragon fruit is very useful to health, but in fact only thought of as waste farming has yet to be used as a good. This study aims to determine comparison levels on the flesh and the dragon red (Hylocereus polyrhizus) with a method spectrophotometry UV-Visible. Method: This type of research using the method of true experimental reseach stage includes preparation of samples, qualitative test, quantitative test, making the solution of the parent raw materials, determination of wavelength of vitamin $C$ and manufacture of the calibration curve. The sample of this study is the flesh and the dragon red (Hylocereus polyrhizus). Results: Based on the results revealed that the fles and the dragon red (Hylocereus polyrhizus. Discussion: Levels on the flesh the dragon red of $0.05888 \mathrm{mg} / \mathrm{mL}$ and The levels of vitamin $C$ on the skin the dragon red of $0.02533 \mathrm{mg} / \mathrm{mL}$.

Keywords : Vitamin $C$, the fles and the dragon red, spectrophotometry uVVisible.

\section{PENDAHULUAN}

Indonesia merupakan wilayah yang beriklim tropis dan berada di daerah khatulistiwa. Ini memungkinkan tumbuhnya berbagai macam tumbuhtumbuhan dengan subur seperti buahbuahan dan sayur sayuran. Buah-buahan mengandung berbagai macam vitamin yang diperlukan oleh tubuh, salah satunya adalah vitamin C. Salah satu zat gizi yang berperan sebagai antioksidan dan efektif mengatasi radikal bebas yang merusak sel atau jaringan, termasuk melindungi lensa dari kerusakan oksidatif yang ditimbulkan oleh radiasi. (Merdiana, 2015).
Vitamin merupakan zat gizi yang terdapat dalam makanan, yang sangat dibutuhkan oleh tubuh manusia. Walaupun dibutuhkan dalam jumlah kecil, peranan vitamin sangat viral bagi pertumbuhan dan perkembangan, pencegahan penyakit dan mencapai kehidupan yang sehat dan optimal. Vitamin sebagai zat gizi mikro tidak dapat di produksi oleh tubuh sehingga harus didapatkan dari makanan. Kekurangan vitamin masih menjadi masalah di dunia. Diperkirakan separuh anak-anak usia 6 bulan sampai 5 tahun di dunia menderita satu atau lebih kekurangan zat gizi mikro, 
dan secara global lebih dari dua juta orang di dunia mengalami kekurangan gizi mikro termasuk vitamin (WHO, 2016).

Salah satu fungsinya membantu mensintesis kolagen (berguna menguatkan pembuluh darah, untuk penyembuhan luka, pembentukan tulang, kekebalan, juga dapat mempercepat penyerapan besi di dalam tubuh, sehingga kadar hemoglobin bisa meningkat. Vitamin C juga bertindak sebagai antioksidan nonenzimatik eksogen yang berpartisipasi dalam pertahanan paru primer terhadap spesies oksigen reaktif. Beberapa penelitian epidemiologi telah menunjukkan bahwa makanan yang kaya antioksidan dapat mengurangi efek ozon pada kesehatan pernapasan (Keranis,dkk.,2012; Marbun., et.al.,2018). Berdasarkan penelitian Risnayanti (2015), kadarnya pada daging buah naga merah sebesar 5,28 mg/100 gram. Buah naga memiliki nilai ekonomi tinggi dan bermanfaat untuk mengobati berbagai jenis penyakit yaitu dapat menurunkan kadar kolesterol, penyeimbang gula darah, mencegah kanker usus, menguatkan fungsi ginjal dan tulang, menguatkan daya kerja otak, meningkatkan ketajaman mata serta bahan kosmetik.

Tumbuhan buah naga termasuk suku Cactaceae, batangnya bercabang banyak, dapat tumbuh berdiri mengikuti penyangganya lalu menjuntai kebawah. Pada cabang tersebut muncul bunga yang akan menjadi buah. Bentuk buahnya unik dan menarik, kulitnya merah dan bersisik hijau mirip sisik seekor naga, sehingga dinamakan buah naga atau dragon fruit (Cahyono, 2015; Kaban, 2018). Buah naga merupakan salah satu tanaman yang sangat potensial untuk dikembangkan, salah satunya yaitu sebagai sumber antioksidan alami.
Kulitnya sangat bermanfaat bagi kesehatan namun pada kenyataannya hanya dianggap sebagai limbah pertanian yang selama ini belum dimanfaatkan secara baik. Kulit buah naga yang dibuang dapat menyebabkan masalah lingkungan, khususnya pencemaran air.

Berjumlah 3035\% dari berat buahnya dan seringkali hanya dibuang sebagai sampah. Padahal hasil penelitian menunjukkan bahwa kulit buah naga mengandung antioksidan dan juga dapat menurunkan kadar kolesterol. Kulit buah naga merah (Hylocereus polyrhizus) mengandung betalain yang berfungsi sebagai antioksidan dan pewarna alami. Kulit buah naga memiliki potensi antioksidan yang lebih besar dibanding buahnya (Darmawi, 2012).

Kulit buah naga merah memiliki kandungan nutrisi seperti karbohidrat, lemak, protein dan serat pangan. Kandungan serat pangan yang terdapat dalam kulit buah naga merah sekitar $46,7 \%$. Kandungn serat kulitnya lebih tinggi dibandingkan dengan buah pear, jeruk dan buah persik. Menurut Santoso (2012) serat pangan memiliki manfaat bagi kesehatan yaitu mengontrol berat badan atau kegemukan, menanggulangi penyakit diabetes, mencegah gangguan gastrointestinal, kanker kolon (usus besar) serat mengurangi tingkat kolesterol darah.

\section{Tujuan Penelitian}

\section{Tujuan Umun}

Untuk mengidentifikasi kadar vitamin $C$ pada daging dan kulit buah naga merah (Hylocereus polyrhizus) dengan metode spektrofotometri UV-Visible.

\section{Tujuan Khusus}

a. Untuk mengetahui kadar vitamin C pada daging buah naga merah (Hylocereus polyrhizus). 
b. Untuk mengetahui kadar vitamin C pada kulit buah naga merah (Hylocereus polyrhizus).

\section{TINJAUAN PUSTAKA}

\section{A. Klasifikasi Buah Naga}

Buah naga termasuk dalam kelompok tanaman kaktus atau famili Cactaceae dan subfamili Hylocereanea. Dalam subfamili ini terdapat beberapa genus, sedangkan buah naga termasuk dalam genus Hylocereus. Genus ini pun terdiri dari sekitar 16 spesies. Dua diantaranya memiliki buah yang komersial, yaitu Hylocereus undatus (berdaging putih) dan Hylocereus polyrhizus (berdaging merah). Adapun klasifikasi buah naga tersebut sebagai berikut.
Kingdom : Plantae
Divisi : Spermatophyta
Subdivisi : Angiospermae
Kelas : Dicotyledonae
Ordo : Cactales
Famili : Cactaceae
Subfamili : Hylocereanea
Genus : Hylocereus
Spesies : Hylocereus undatus (daging putih), Hylocereus polyrhizus (berdaging merah), Hylocereus costaricensis (berdaging merah super), Selenicereus megalanthus (kulit kuning, tanpa sisik).

\section{B. Morfologi Buah Naga}

Tanaman yang berasal dari Meksiko, Amerika Tengah dan Amerika Selatan bagian utara ini sudah lama dimanfaatkan buahnya untuk konsumsi segar. Namun, selama itu tidak satu pun media massa dunia yang memberitakannya. Saat ditemukan dialam aslinya, tanaman ini memanjat batang lain di hutan yang teduh. Walaupun perakarannya di tanah, tanaman ini masih tetap hidup sebagai epifit karena kebutuhan makanannya diperoleh melalui akar udara pada batangnya. Secara morfologis, tanaman ini termasuk tanaman tidak lengkap karena tidak memiliki daun. Untuk mengenal lebih jauh mengenai sosok tanaman ini, berikut diulas morfologinya yang terdiri dari akar, batang dan cabang, bunga, buah, dan biji.

\section{Manfaat Daging Buah Naga}

Dari beberapa media massa disebutkan bahwa daging buah naga memiliki khasiat untuk kesehatan manusia, di antaranya ialah sebagai penyeimbang kadar gula darah, pencegah kanker usus, pelindung kesehatan mulut (sariawan), pengurang kolesterol, pencegah pendarahan, tekanan darah tinggi, bahan kosmetik, meningkatkan kekebalan tubuh, dan obat keluhan keputihan. Adanya khasiat-khasiat tersebut disebabkan oleh kandungan nutrisi dalam buahnya yang sangat mendukung kesehatan tubuh manusia.

\section{Manfaat Kulit Buah Naga}

Berdasarkan uji klinis, ternyata tak hanya daging buah naga yang menyimpan sejuta khasiat. Kulitnya yang cerah dan cenderung bersisik juga diketahui mengandung senyawa aktif seperti pentacyclic triyepene taraxast 20ene 3aol dan juga taraxast 12,20(30)dien 3aol. Kedua senyawa ini sangat ampuh menjaga serta melindungi kelenturan pembuluh darah. Bahkan keampuhan ini menyamai obat Troxerutin yang dikenal sebagai obat berbahan kimia yang digunakan untuk melindungi pembuluh darah mikro. Obat ini banyak beredar dipasaran dan populer digunakan untuk mereduksi potensi pembuluh darah pecah. Dengan ditemukannya kandungan pada kulit buah naga ini, tentu akan menjadi alternatif alami untuk mencegah pecahnya pembuluh darah. 
Jurnal Farmasi, e-ISSN: 2655-0814

Vol. 2 No.1 Edisi Mei-Oktober 2019

http://ejournal.medistra.ac.id/index.php/JFM

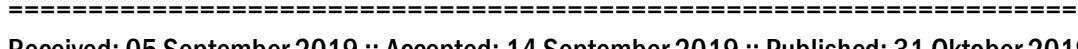

\section{E. Vitamin C}

Vitamin C adalah vitamin larut dalam air selain vitamin B kompleks. Selain menjalankan fungsinya sebagai nutrisi bagi tubuh, dan juga merupakan antioksidan sekunder sekaligus sebagai antioksidan tersier, salah satunya donor elektron yang menyumbang elektron kedalam reaksi biokimia intra dan ekstra seluler. Keberadaannya mampu mereduksi oksigen reaktif dalam sel monosit, netrofil, lensa dan retina mata. Vitamin $C$ sanggup mereduksi radikal superoksida, peroksida, hidroksil, asam klorida, dan oksigen reaktif dari netrofil dan monosit yang teraktivitasi (Lingga, 2012).

Asam askorbat mempunyai berat molekul 176,13 dengan rumus molekul C6H806. Senyawa ini bersifat reduktor kuat dan mempunyai rasa asam. mudah larut dalam air (1 g dapat larut sempurna dalam $3 \mathrm{ml}$ air), sedikit larut dalam alkohol (1 g larut dalam $50 \mathrm{ml}$ alkohol atau $100 \mathrm{ml}$ gliserin) dan tidak larut dalam benzen, eter, kloroform, dan minyak.

\section{F. Spektrofotometri UV-Visibel}

Spektrofotometer visible adalah pengukuran panjang gelombang dan intensitas sinar ultraviolet dan cahaya tampak yang diabsorpsi oleh sampel. Sinar tampak berada pada panjang gelombang 400-800 nm. Spektrum ini sangat berguna untuk pengukuran secara kuantitatif (Ompusunggu, 2012).

Bisa juga disebut alat untuk mengukur transmitan atau absorben suatu contoh sebagai fungsi panjang gelombang, pengukuran terhadap suatu deret contoh pada suatu panjang gelombang tunggal mungkin juga dapat dilakukan. Alat-alat demikian dapat dikelompokkan baik sebagai manual atau perekam, maupun sebagai sinar tunggal atau sinar tangkap (Day dan Underwood, 2013).

Prinsip dari alat ini yaitu radiasi pada rentang panjang gelombang 400-800 nm dilewatkan melalui suatu larutan senyawa. Elektron-elektron pada ikatan didalam molekul menjadi tereksitasi sehingga menempati keadaan kuantum yang lebih tinggi dan dalam proses menyerap sejumlah energi yang melewati larutan tersebut. Semakin longgar elektron tersebut ditahan di dalam ikatan molekul, semakin panjang gelombang (energi lebih rendah) radiasi yang diserap. Suatu spektrofotometer tersusun dari sumber spektrum tampak yang kontinyu, monokromator, sel pengabsorpsi untuk larutan sampel atau blanko dan suatu alat untuk mengukur perbedaan antar sampel dan blanko ataupun pembanding (Khopkar, 2013).

\section{METODE PENELITIAN}

\section{Alat}

Alat - alat yang digunakan adalah timbangan analitik, corong, spatel, kertas saring Whatman no 1 , labu ukur, gelas ukur, cawan porselin, beaker gelas, tabung reaksi, corong, pipet volum, neraca Analitik, pipet tetes, dan alat Spektrofotometri UV - Visibel (UV mini1240).

\section{Bahan}

Bahan - bahan yang digunakan adalah daging dan kulit buah naga merah (Hylocereus polyrhizus), larutan metilen biru, asam askorbat, $\mathrm{NaOH} 10 \%$, FeSO4 $5 \%$ dan aquabidest.

\section{Pengolahan Sampel}

Sampel yang digunakan adalah daging dan kulit buah naga merah. Daging dan kulit buah naga merah dicuci dengan air yang mengalir dan ditiriskan, dipotong kasar, dihaluskan dengan blender dan 
ditimbang masing-masing sebanyak 50 mg untuk uji kualitatif dan 100 mg untuk uji kuantitatif.

\section{Uji Kualitatif}

1. Pada $2 \mathrm{ml}$ larutan sampel ditambahkan 4 tetes metilen biru, hangatkan hingga suhu $40^{\circ} \mathrm{C}$ terjadi warna biru tua dalam waktu 3 menit berubah menjadi lebih muda atau hilang.

2. Pada $2 \mathrm{ml}$ larutan sampel ditambahkan 2 tetes $\mathrm{NaOH} \quad 10 \%$ kemudian ditambahkan $2 \mathrm{ml}$ FeSO $45 \%$ amati perubahan warna yang terjadi, reaksi positif ditandai dengan terbentuknya warna kuning.

\section{Pembuatan Larutan Induk Baku Vitamin C 100 ppm}

Asam askorbat ditimbang sebanyak 50 mg kemudian dimasukkan ke dalam labu ukur $500 \mathrm{ml}$ dan di larutkan dengan aquabidest sampai tanda batas.

\section{Analisis Kuantitatif Panjang Gelombang Maksimum Larutan Vit C}

\section{Penentuan} Serapan

Dipipet $5 \mathrm{ml}$ larutan vitamin C 100 ppm dan dimasukkan ke dalam labu tentukur $50 \mathrm{ml}$ (konsentrasi 10 ppm) lalu ditambahkan aquabidest sampai tanda batas dan homogenkan. Di ukur serapan maksimum pada panjang gelombang 200$300 \mathrm{~nm}$ dengan menggunakan blanko aquabidest.

\section{Pembuatan Kurva Kalibrasi}

Di pipet larutan vitamin C 100 ppm kedalam labu ukur $50 \mathrm{ml}$ masing - masing sebesar $2 \mathrm{ml}, 3 \mathrm{ml}, 4 \mathrm{ml}, 5 \mathrm{ml}$ dan $6 \mathrm{ml}$ ( 4 ppm, 6 ppm, 8 ppm 10 ppm dan 12 ppm). Kemudian ditambahkan aquabidest hingga tanda batas homogenkan dan ukur serapannya pada panjang gelombang maksimum yang di peroleh.

\section{HASIL DAN PEMBAHASAN}

Analisis kualitatif dilakukan sebagai analisis pendahuluan untuk mengetahui ada atau tidaknya vitamin $\mathrm{C}$ dalam sampel.

Tabel 4.1. Hasil Analisis Kualitatif

\begin{tabular}{|c|c|c|c|c|}
\hline No & Sampel & $\begin{array}{c}\text { Pereaks } \\
\text { i }\end{array}$ & $\begin{array}{c}\text { Hasil } \\
\text { Reaksi }\end{array}$ & Hasil \\
\hline 1 & $\begin{array}{c}\text { Daging } \\
\text { Buah Naga } \\
\text { Merah }\end{array}$ & $\begin{array}{c}\text { NaOH } \\
10 \% \text { dan } \\
\text { FeSO4 } 5 \\
\%\end{array}$ & Kuning & + \\
\hline 2 & $\begin{array}{c}\text { Kulit Buah } \\
\text { Naga } \\
\text { Merah }\end{array}$ & $\begin{array}{c}\text { NaOH } \\
10 \% \text { dan } \\
\text { FeSO4 } 5 \\
\%\end{array}$ & Kuning & + \\
\hline 3 & $\begin{array}{c}\text { Duah Naga } \\
\text { Merah }\end{array}$ & $\begin{array}{c}\text { Metilen } \\
\text { Biru }\end{array}$ & Biru Tua & + \\
\hline 4 & $\begin{array}{c}\text { Kulit Buah } \\
\text { Naga } \\
\text { Merah }\end{array}$ & Metilen \\
& Biru & Biru Tua & + \\
\hline
\end{tabular}

Keterangan : $+=$ Mengandung vitamin C

Tabel di atas menunjukkan bahwa daging buah naga merah dan kulit buah naga merah, mengandung vitamin $C$. Sampel di katakan positif, jika menghasilkan warna kuning dengan penambahan $\mathrm{NaOH} 10 \%$ dan $\mathrm{FeSO} 4$ 5\%, dan menghasilkan warna biru tua dengan penmbahan Metilen Biru (Svehla, 2012).

\section{Analisis Kuantitatif Penentuan Kadar Baku Pembanding Vitamin C}

Hasil penetapan kadar asam askorbat p.a (pro analisis) dengan metode spektrofotometri UV-Vis diperoleh kadar rata-rata 224,5 $\mathrm{nm}$. Penetapan kadar dilakukan dengan metode spektrofotometri UV-Vis karena pelaksanaannya relatif cepat dan 
Jurnal Farmasi, e-ISSN: 2655-0814

Vol. 2 No.1 Edisi Mei-Oktober 2019

http://ejournal.medistra.ac.id/index.php/JFM

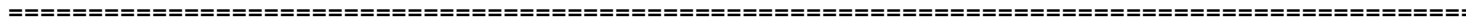

Received: 05 September 2019 :: Accepted: 14 September 2019 :: Published: 31 Oktober 2019

sederhana dengan menggunakan pelarut aquabidest. Penentuan kadar baku pembanding ini bertujuan untuk mengnolkan skala absorbansi setiap selesai satu pengukuran dan dihitung nilai absorbansi rata-rata.

\section{Penentuan Panjang gelombang Maksimum}

Panjang gelombang yang digunakan untuk melakukan analisis panjang gelombang dimana suatu zat memberikan penyerapan paling tinggi. Hal ini disebabkan jika pengukuran dilakukan pada panjang gelombang yang sama, maka data yang diperoleh semakin akurat. Hasil pengukuran yang maksimum dari asam askorbat diperoleh pada pengukuran di panjang gelombang yang memberikan serapan maksimum dengan konsentrasi $2 \mathrm{ml}$ ( 4 ppm).

\section{Kurva Kalibarasi} kalibrasi merupakan perbandingan antara konsentrasi dengan nilai absorban. Semakin besar konsentrasinya maka nilai absorbannya akan semakin besar pula. Kurva kalibrasi juga digunakan untuk menentukan kadar asam askorbat dalam sampel, Pada penelitian ini, Penentuan kurva kalibrasi larutan vitamin $\mathrm{C}$ dilakukan dengan cara mengukur serapan larutan baku dengan konsentrasi 4 ppm, 6 ppm, 8 ppm, 10 ppm dan 12 ppm yang ditambahkan dengan pelarut aquabidest, kemudian diukur pada panjang gelombang 224,5 nm. Hasil pengukuran kurva kalibrasi dapat dilihat pada Tabel 4.2 dan Grafik 4.2 berikut:

Tabel 4.2. Hasil Pengukuran Kurva Kalibrasi Vitamin C

\section{\begin{tabular}{|l|l|l|}
\hline No & Konsentrasi & Absorbansi \\
\hline
\end{tabular}}

\begin{tabular}{|c|c|c|}
\hline & (ppm) & \\
\hline 1 & 0,000 & 0,000 \\
\hline 2 & 4 & 0,061 \\
\hline 3 & 6 & 0,114 \\
\hline 4 & 8 & 0,155 \\
\hline 5 & 10 & 0,209 \\
\hline 6 & 12 & 0,242 \\
\hline
\end{tabular}

\section{Penetapan Kadar Vitamin C Pada Sampel}

Kadar vitamin C pada daging dan kulit buah naga merah dapat ditentukan dengan cara Spektrofotometri UV-Visible. Pada metode ini, larutan sampel diletakkan pada sebuah kuvet yang disinari oleh cahaya UV dengan panjang gelombang $224,5 \mathrm{~nm}$. Pemilihan metode ini dilakukan dengan alasan bahwa analisis menggunakan metode ini memiliki hasil yang akurat (Monalisa., dkk. 2013).

Konsentrasi vitamin C dalam sampel ditentukan berdasarkan persamaan garis regresi linier kurva kalibrasi larutan standar vitamin C. karena konsentrasi vitamin $\mathrm{C}$ yang terdapat dalam daging dan kulit buah naga merah terlalu besar, maka perlu pengenceran 3 kali, agar berada dalam rentang kurva kalibrasi vitamin $\mathrm{C}$. Pengenceran ini dilakukan agar konsentrasi larutan berkurang atau semakin kecil. Penetapan kadar vitamin C pada daging dan kulit buah naga merah dilakukan sebanyak 3 kali pengulangan, dengan maksud untuk mengetahui dan membandingkan hasil dari setiap sampel yang diuji.

Tabel 4.3. Hasil Analisis Kadar (mg/100 $\mathrm{ml}$ )

\begin{tabular}{|l|l|}
\hline $\begin{array}{l}\text { Buah Naga } \\
\text { Merah }\end{array}$ & $\begin{array}{l}\text { Kadar Vitamin C } \\
\mathbf{( m g / 1 0 0} \mathbf{~ m l})\end{array}$ \\
\hline Daging & $0,05888 \mathrm{mg} / \mathrm{mL}$ \\
\hline Kulit & $0,02533 \mathrm{mg} / \mathrm{mL}$ \\
\hline
\end{tabular}


Kadar Vitamin C dalam suatu sampel ditentukan dengan metode spektrofotometri UV-visible yang dapat dihitung dengan menggunakan persamaan $y=a x+b$, sehingga berdasarkan perhitungan diperoleh kadar Vitamin C pada sampel. Berdasarkan hasil analisis kadar vitamin $\mathrm{C}$ pada daging buah naga merah mempunyai nilai kadar vitamin C yang tinggi dibandingkan kulit buah naga merah. Hasil tersebut menunjukkan bahwa diperoleh tidak jauh berbeda antara daging dan kulit buah naga merah.

Hasil percobaan penetapan pada daging dan kulit buah naga merah yang diperoleh pada penelitian ini adalah $0,05888 \mathrm{mg} / \mathrm{mL}$ dan $0,02533 \mathrm{mg} / \mathrm{mL}$. Dari hasil yang diperoleh terjadi perbedaan yang cukup banyak dengan hasil penelitian terdahulu. Menurut Risnayanti (2015), kadar vitamin C pada daging buah naga merah sebesar 5,28 mg/100 gram. $\mathrm{Hal}$ ini dikarenakan perbedaan berat sampel yang digunakan, pada penelitian ini sampel yang digunakan hanya $100 \mathrm{mg}$ sedangkan pada penelitian terdahulu sebanyak $200 \mathrm{mg}$. Sehingga hasil yang diperoleh tidak sebanding dengan kebutuhan asupan Vitamin $\mathrm{C}$ per harinya yang ditetapkan oleh Recommended Daily Allowance (RDA) untuk remaja usia 11-14 tahun adalah $50 \mathrm{mg} /$ hari dan usia 15-18 tahun $60 \mathrm{mg} /$ hari (Silalahi, 2016).

\section{KESIMPULAN DAN SARAN}

\section{Kesimpulan}

Pemeriksaan secara kuantitatif dengan menggunakan spektrofotometri UV-visible dengan panjang gelombang 224,5 nm menunjukkan bahwa pada daging buah naga merah sebesar $0,05888 \mathrm{mg} / \mathrm{mL}$. Pemeriksaan secara kuantitatif dengan menggunakan spektrofotometri uv visible dengan panjang gelombang $224,5 \mathrm{~nm}$ menunjukkan bahwa pada kulit buah naga merah sebesar $0,02533 \mathrm{mg} / \mathrm{mL}$.

\section{Saran}

Disarankan untuk peneliti selanjutnya dapat meneliti kadar vitamin $C$ pada buah naga merah dan kulit buah naga merah dengan metode lain, misalnya metode Kromatografi Cair Kinerja Tinggi (HPLC).

\section{DAFTAR PUSTAKA}

Cahyono, J.B.\& Suharjo B.(2015). Hepatitis A. Edisi I. Yogyakarta: Kanisisus.

Darmawi A.W. (2012). Optimasi proses ekstrksi, pengaruh $\mathrm{pH}$ dan jenis cahaya pada aktivitas antioksidan dari kulit buah naga merah (Hylocereus polyrhizus).

Day, R.A., dan Underwood, A.L. (2013). Quantitative Analysis. Diterjemahkan oleh Soendoro, R. Widaningsih, W.B.A., dan Sri, R.S., Analisa Kimia Kuantitatif. (203). Jakarta: Erlangga. Hal. 222.

Gandjar, G. H., dan Rohman, A. (2013). Kimia Farmasi Analisis. Pustaka Pelajar: Yogyakarta: hal.120, 164, 166.

Kaban, V., \& Yusmarlisa, S. (2018). Uji aktivitas kandungan antioksidan pada daun bangun bangun (plectranthus amboinicus) secara spektrofotometri ultraviolet visible. Jurnal farmasimed (JFM), 1(1), 16-20. https://doi.org/10.35451/jfm.v1i1 .90

Keranis, E. dkk. (2012). Impact of dietary shift to higher antioxidant foods in copd a randomized trial. Eur Respir J, 36(4), 774-780.

Khopkar, S. M. (2013). Konsep Dasar Kimia Analitik. UI-Press, Jakarta. 
Lingga, Lanny. (2012). Sehat dan Sembuh Dengan Lemak. Jakarta: PT. Alex Media Komputindo.

Marbun, R., Situmorang, N., \& Wahyuni, S. (2018). The efect of immunomodulator by extract ethanol of herba binara (artemisia vulgaris I.) Toward the response of delayed-type hypersensitivity in rat male. Jurnal Penelitian Farmasi \& Herbal, 1(1), 17-21. Retrieved from

http://ejournal.delihusada.ac.id/in dex.php/JPFH/article/view/59.

Merdiana Prasetyani Putri. (2015). Analisis Kadar Vitamin $C$ pada Buah nanas Segar (Ananas comosus L.) dan Buah Nanas Kaleng Dengan Metode Spektofotometri uvvis.Jurnal Wiyata, vol.2 No.1 tahun 2015.

Ompusunggu, H. (2012). Analisa Kandungan Nitrat Air Sumur Gali Masyarakat di Sekitar Tempat Pembuangan Sampah (TPS) di Desa Namo Bintang 11 Kecamatan Pancur Batu.

Risnayanti, Sri Mulyani Sabang dan Ratman. (2015). Analisis Perbedaan Kadar Vitamin C Buah Naga Merah (Hylocereus polyrhizus) dan Buah Naga Putih (hylocereus undatus) yang Tumbuh Di Desa Kolono Kabupaten Morowali Provinsi Sulawesi Tengah. Jurnal J. Akad. Kim. Vol. 4 (2):91-96, May 2015.

Silalahi, J. (2016). Makanan Fungsional. Yogyakarta: Penerbit Kanisius. Hal. 52-53.

Svehla. (2012). Textbook of Macro and Semimicro Qualitative Inorganic Analysis. Penerjemah Setiono dan Hadyana Pudjaatmaka. Kimia Analisis Kualitatif Anorganik. (1990). Edisi kelima Bagian I.
Jakarta: PT. Kalman Media

Pusaka. Halaman 262-263.

WHO (World Health Organization). (2016). Micronutrien 